\title{
An Exploration of the Impact of Jewish Dissension on Philip Roth's Fiction Writing
}

\author{
Hongmei Chen ${ }^{1}$ \\ ${ }^{1}$ College of Foreign Languages at Nanjing Forestry University, P. R. China
}

\begin{abstract}
Philip Roth used to take advantage of his biographical details and experience to write his fiction. This essay traces the history from the reception for his Goodbye, Columbus to his settling down on this technique in Zuckerman Bound, and holds that the fierce dissention between him and the Jewish community has played a key role shaping his writing about himself, and that the friction resulted from the fact that American Jews, who narrowly escaped from the Holocaust, treasured the secure life in the US, feared that any disclosure of the dark or humiliating side of Jewish life would have led to actions against them. Roth, in so writing of himself, has thus built up a peculiar world of his fiction.
\end{abstract}

Keywords: Philip Roth, the Jewish reader's response, ventriloquism

\section{Introduction}

There is much criticism observing the shift in Philip Roth's way of writing from being seriousness to playing comic. Alan Cooper, an expert in Roth studies, finds that “everything since Portnoy['s Complaint](1969) has been overtly comedic, as everything before Portnoy seemed more or less "serious." "[1]82 The "serious[ness]" Cooper mentioned is different from that in Roth's motto "sheer playfulness and deadly seriousness are my closest friends" ${ }^{\prime[2] 98}$ in that the former refers to tone and style while the latter is mainly meant thematically. Cooper's statement makes sense though it is somewhat an exaggeration to say so of all the works before or after Portnoy's, he actually is not alone. Donald Kartiganer holds that the characters in the novels before Portnoy's are "forceful but static"[3]87, and that only "with Portnoy's Roth displayed fully for the first time the comic possibilities of metamorphosis." ${ }^{[3] 100}$ Though Kartiganer, in a different way than Cooper, approaches to Roth in terms of character, he draws the same conclusion as the latter. To the two critics, Portnoy's Complaint is the pivot in Roth's career, and Roth, the writer himself, took it, in the interviews with Carol Joyce and George Plimpton, as his first mature novel, those before as apprenticeship or not of himself. From those interviews with Roth and his works before and after Portnoy's, it can be seen that the reader's response to Goodbye, Columbus(1959) of the Jewish community has played a critical role in Roth's writing Portnoy's Complaint and exploring his fiction writing, and led to his preference for exposing his personal life in his works.

\section{The Jewish Dissention}

Philip Roth had a successful start-up in his career. His first book, Goodbye, Columbus, won him bursts of applause from literary gurus like Alfred Kazin, Saul Bellow and Irving Howe, etc, and brought him the prestigious National Book Award in 1960. Critics praised him for his observant and acute lampoonings on society, and witty way of writing. In the meantime, the book stirred huge splash of chastise from the institutions of the Jewish community because of Roth's portrayal of the outdated and dark sides of Jewish life and doubts about Judaism though. The stories, "The Conversion of the Jews" and "The Defender of the Faith", were the two spots of crossfire. Not only has Roth mocked the faith of Jewish people, but disparaged the close tie in Jewish brotherhood. In addition, the story "Epstein" caused embarrassment to rabbis as well as common Jewish people because the sixty-year-old Epstein, founder of a paper bag company, commits adultery with the woman across the street. Many Jewish readers simply couldn't figure out why the author wrote such a humiliating story of a Jew, nor could they understand how a Jew can ignore his work and indulge in the relationship. These stories imposed great annoyance on quite a lot of Jewish people, rabbis in particular. In the interview with The London Sunday Times, Roth mentioned that he was impressed by the demand of a prominent rabbi in New York on the Anti-Defamation League of the B'nai Brith that something be done to silence him $^{[4] 133}$. Many of the enraged readers protested either by writing to Roth or the magazine in which the stories got published or challenging Roth on the occasion when he was invited to meet Jewish people at synagogues and community centers. Fortunately, such terrible protest didn't result in action in the country where freedom of speech is practiced, but Roth was labeled as self-hatred and antiSemitism, rebelling against the ethnicity into which he was born.

Like Father says in The Ghost Writer(1979), the commonplace reader takes literary works as reality, equating fictional characters with real people. But Goodbye, Columbus was published at a period when American Jews enjoyed the rare peace and security shortly after their tribesmen in Europe were stricken by the Holocaust. They were sensitive and fearful that any exposure to the gentile of the unfavorable part concerning the Jewish people would have incurred anti-Semitism for which the Jews have paid highly costs of wealth and life in the long history of Diaspora. The US is not immune to anti-Semitism, but the Jewish couldn't be negligent of any misinforming and 
paying any more price. Consequently, they especially cherished their peaceful life. So Roth was helpless and terribly pressured when faced with such accusation.

Confronted with the cascades of the criticism, Roth couldn't hold back and did what he could. On the one hand, he accepted invitations to answer the challenges at the gatherings in the Jewish institutions and communities. On the other hand, he reflected on his own writing when such huge rage from the audience was forced on him. Roth reacted to the response in three ways later in his career. Firstly, Roth tried to stay away from the topics and issues which he got bumped by in Goodbye, Columbus. The immediate result is that Letting Go(1962) and When She Was Good(1967) were kept diametrically different from those in the collection, the former with no Jewish characters in it whereas the latter purely neat, without one dirty word or scene. But Roth's efforts in the two books were not successful. The narration in Letting Go is plain, and the structure is so loose that it almost falls into apart ${ }^{[3] 38}$, and Roth himself was dissatisfied, either, finding them "as gloomy as the gloomiest of [some literary] blockbusters," $[4] 22$ and desperately looking for a way to put another part of his talent to play "to write something freewheeling and funny" ${ }^{[4] 21-22}$. At that time, the comment of the prominent Jewish critic, Irvin Howe, may have offered him inspiring sparkle, that "[i]t [Goodbye, Columbus] is ferociously exact. Indeed, that is the trouble: it is too exact, too close to surface realities, there is not enough imaginative transformation" ${ }^{\text {"[5]18 }}$, for Howe was then a well-established writer to whom Roth looked up.

After the terrible trial and hard work on the fourth or more abandoned drafts writing his fourth book, Portnoy's Complaint, Roth has finally come to his determination, "Well, you want it, I'll give it to you. And out came Portnoy, apertures spurting." "[4]134 The criticism on his too exact writing about people around him and exposing the dark side of the Jews to the gentile dared him to portray unfavorably the inside of Jewish family life. His experience of having been analyzed has also helped him find the confessional narrative strategy. "I was trying to blow up more of myself. This phenomenon is known to students of literary survey courses as the writer is changing his style. I was blowing up a lot of old loyalties and inhibitions, literary as well as personal." ${ }^{[4] 155}$ His sticking close to the fact and narrowing the gap between the actual and the fictional were so successful that a woman reader in East Orange, New Jersey, even wrote to tell him that she knew his sister, that is, Alex Portnoy's sister, Hannah while Roth has no sister, but a brother, Sandy.

The "pseudo-autobiographical" feature of Portnoy's Complaint is manifest not only in its confessional narration of psychoanalysis, but what is told in the self-claim. A critic has compared this novel and Hans J. Kleinschimdt's psychoanalysis of Roth and holds that Portnoy's Complaint is autobiographical ${ }^{[6] 29-31 ; 41}$. Besides Alex's adolescent transgressing the Jewish cultural taboos on respect for parents, sex, kosher dietary and pursuit of gentile women which is strikingly appealing to readers at that time, the author's biographical details also bestow the work stark autobiographical taint that can be "vouch[ed] for observation and experience."[4]40 Recurring reference of places such as Weequaic Jewish High School, Chancellor Street, etc. in Roth's hometown creates a factual "Yoknapatawpha." The advantage of the lopsided confessional narrative strategy, the silent analyst and, most importantly of all, the never-stop-talking-of-his-mind analyzed has given factuality and consistency to the whole book, which is quite different from the tonelessness and plainness in his previous three works, and satisfies the voyeurism of the controversial writer of Goodbye, Columbus in the audience by "tak[ing] things more aggressively in hand, to strike back at accusations that I had divulged Jewish secrets and vulgarly falsified Jewish lives by upping the ante in Portnoy's Complaint.",[7]116 And it became a great hit at its delivery, Roth lionised by the mass media.

From Roth's own essays and many of his interviews, it can be seen that the Jewish reader's response to his Goodbye, Columbus has made direct impact on his writing Portnoy's Complaint as it is, and Roth has enjoyed the fame and fortune the latter has brought to him, how to maintain such a focus to the audience and the media has been on Roth's mind since. With his success on Portnoy's Complaint, Roth collected himself and fired back, exposing himself and taking advantage of his experience in his early career. There have been many spots of minor counterattacks in his quartet of Zuckerman Bound, which is made up of The Ghost Writer, Zuckerman Unbound(1981), The Anatomy Lesson(1983) and its sequel The Prague Orgy(1985), presumably parodying Howe in the character of Milton Appel who criticized that he was vulgar in Portnoy's Complaint despite the writer's talent and having Zuckerman's jaw broken on a tombstone because of the New York rabbi's calling on to silence him $^{[4] 133}$, to name a few. Roth acknowledged and might well take pride in some cases of such exploits. In the interview with The Paris Review, Roth recalled, "[T]he moral atmosphere of the Portnoy household, in its repressive aspects, owes a lot to the response of persistent voices within the official Jewish community to my debut. They did much to help make it seem auspicious." ${ }^{[4] 156}$ Roth was honest with his conception of Portnoy's Complaint.

\section{The Impact of the Dissention}

The following decade was dull but pregnant to Roth, who, in face of the intensely mixed reception of Portnoy's Complaint, didn't continue his way of writing as he did though he enjoyed himself a lot in so doing. Roth tried something different. The next publication, Our Gang(1971), an attempted third-person Swiftian satire on President Richard Nixton and his administration, proved a flat failure. In 1974, Roth did publish his "autobiographical" writing of My Life as a Man and come up with Nathan Zuckerman for the first time, but stirred up little response among the critic community and the reader alike. Roth found himself 
confined by the dissension he experienced because of his debut $^{[7] 129}$, and came to utilize the controversy over Goodbye, Columbus and Portnoy's Complaint more consciously and consistently. For this, Roth mentions in his autobiography The Facts that "the ramifications of the uproar it[Goodbye, Columbus] fermented eventually inspired me to crystallize the public feud into the drama of internal family dissention that's the backbone of the Zuckerman series, which began to take shape some eight years later."[7]116-17 Nathan Zuckerman has shown up prominently for his resemblance with his creator, donning not only the writer's biography, but also sharing his life story, having thus been acclaimed as the alter ego of Roth. Since The Ghost Writer, Roth has fired back sporadically in the follow-up books.

Naturally, it would not be so easy to make for a master by just writing about the author in the factual manner. With his fiction staying close to the environs in which he himself grew up, Roth found "the more I stuck to the actual and the strictly autobiographical, the less resonant and revealing the narrative became." ${ }^{[4] 37}$ Roth had to, and did imbue his fiction with "impersonation," "ventriloquism," "irony". Talking with Hermione Lee in 1984, Roth explained his skill of so writing,

Think of the ventriloquist... His art consists of being present and absent; he's most himself by simultaneously being someone else, neither of whom he "is" once the curtain is down. You don't necessarily, as a writer, have to abandon your biography completely to engage in an act of impersonation. It may be more intriguing when you don't. You distort it, caricature it, parody it, you torture and subvert it, you exploit it - all to give the biography that dimension that will excite your verbal life ${ }^{[4] 144}$.

The key to this "impersonation" technique lies in keeping the distance between the masque and the origin of the voice while erasing the distance. In the masque, the voice represents different selves, or the self and the other, the larger the distance or fissure between them, the more unwilling the masque is to be dropped off, the more credible and significant the character is. Roth recalled in his writing The Anatomy Lesson that he was greatly fascinated with it because everyone in it is split, full of cracks and fissure, and Zuckerman cannot hide or heal them, like ordinary people do. Roth tried first to put his "impersonation" into use in The Ghost Writer, Nathan donning Roth, and Amy Bellette impersonating Anne Frank, "a woman inventing herself within his[Nathan's] creation." By the end of the 1970s, Roth has become more of himself in his career of writing.

\section{Conclusion}

Although Roth claimed that he was only interested in being a writer, not a Jew, he tried to write, with depth and originality, about some important issues in contemporary Jewish life after he realized that he was a Jew whether he admitted to it or not, and that he was expected to be a Jewish writer and even confined to it after almost thirty years' struggle. Nathan Zuckerman has been Roth's brandname figure after the success of the quartet of Zuckerman Bound and The Counterlife, with the latter enlisted on the finalist of the National Book Award and winning for him the National Critics Circle Award in 1986. After inviting Zuckerman into his autobiography of The Facts to make comments on his writing about his life, Roth removed the barrier between the factual and the fictional, and gradually managed to develop a Rothian feature of artistic tension in his novels, turning Nathan Zuckerman into "Philip", "Philip Roth" in Deception(1990), and "Philip Roth" in Operation Shylock, A Confession(1993), by both of which Roth stood at the climax of his self-inventing and life-writing, and succeeded proving himself a master by winning the Pulitzer Prize and winning the Faulkner Pen Award which is better known for its emphasis on literary originality.

For Roth's trial and hard work at his way of writing, Derek Parker Royal once remarked, "Without the fame of and reaction to Portnoy's Complaint, there may have never been a Zuckerman or a literary character named 'Philip Roth' obsessed with the production of the self. These texts and countertexts live in a symbiotic manner, and it is in this complementary relationship that the subject of fiction and autobiography comes into play." ${ }^{[8] 70}$ Royal made sense pointing out the influence of Portnoy's Complaint on Roth's later works, but it can also be further observed that there would have been no Portnoy had Goodbye, Columbus been received otherwise, as is demonstrated above. It can still be argued that Roth, by portraying Portnoy autobiographically, exposing and transgressing the taboos in Jewish family life, and transforming himself into characters like Nathan Zuckerman and "Philip Roth," etc. has produced one unique fictional world to readers of his in all corners on the earth.

\section{Acknowledgments}

Sponsored by Fellowship for Studies in Philosophy and Social Sciences for University and College, Jiangsu Provincial Department of Education, the program of "A Study on the Other in Contemporary American Jewish Literature (2014SJB040).”

\section{References}

[1]Cohen, Sara Blacher. ed. 1987. Jewish Wry. Bloomington and Indianapolis: Indiana University Press.

[2]Searles, George J. ed. 1992. Conversations with Philip Roth. Jackson: University Press of Mississippi.

[3]Pinsker, Sanford. ed. 1982. Critical Essays on Philip Roth. Boston: G. K. Hall \& Co.

[4]Roth, Philip. 1974. Reading Myself and Others. New York: Penguin Books. 
[5]Howe, Irving. 1959. "The Suburbs of Babylon." The New Republic. 24 (June 15): 17-18.

[6]Rudnytsky, Peter L. 2007. "True Confessions in Operation Shylock." Philip Roth Studies. 3: 26-43.
[7]Roth, Philip. The Facts. 1988. New York: Farrar, Straus and Giroux.

[8]Halio, Jay L. and Ben Siegel, eds. 2005. Turning up the Flame: Philip Roth's Later Novels. Newark NJ: University of Delaware Press. 